\title{
Türkiye Ekonomisinde İhracat ve Döviz Kuru Oynaklığı İlişkisi
}

\author{
Export and Exchange Rate Volatility Relationship in Turkish Economy \\ Cüneyt SEVIM ${ }^{1}$, Taylan Taner DOĞAN²
}

\begin{abstract}
ÖZET
Bu çalışmada temel olarak döviz kuru oynaklığının ihracat üzerindeki etkisi incelenmiştir. Türkiye'nin en çok ihracat yaptığı beş ülke olan Almanya, Fransa, İtalya, Ingiltere ve Amerika Birleşik Devletleri'nin Ocak 2002 - Kasım 2014 dönemi verileri, ARDL Sınır Testi Yaklaşımı ile analiz edilmiştir. Ayrıca reel döviz kuru ve ihracat yapılan ülkelerin endüstriyel üretim endeksinin de ihracata etkisi incelenmiştir. Ulaşılan sonuçlar teorik beklentilere karşın döviz kuru oynaklığının ne kısa ne de uzun dönemde ihracat üzerinde anlamlı bir etkisi olmadığı yönündedir.
\end{abstract}

Anahtar Kelimeler: İhracat, Döviz Kuru Oynaklığı, ARDL Sınır Testi Yaklaşımı

\section{GiRiş}

Döviz kuru oynaklığı, bir yandan ihracat ile ekonomik büyümelerini hızlandırmak isteyen gelişmiş ülkeler, diğer yandan kalkınmalarını ihracata dayayan gelişmekte olan ülkeler için çok önemli bir olgudur. Özellikle 1973 yılında Bretton Woods Sisteminin tamamen yürürlükten kaldırılması ile esnek kur sisteminin yaratacağı oynaklık neredeyse tüm iktisatçıları endişelendirmiştir. Zira oynaklığın yaratacağı belirsizlik tüm uluslararası ticareti sekteye uğratarak ekonomik krizler yaratabilecektir.

Öyle ki finansal kriz literatürü incelendiğinde finansal krizin döviz kuru, faiz oranı ve Merkez Bankası Rezervlerindeki değişimin kendi ortalamasından sapması ile tanımlandığı görülecektir (Sevim, Oztekin, Bali, Gumus, \& Guresen, 2014). Bu nedenle olsa gerek döviz kuru oynaklığının ihracat üzerindeki etkisi uluslararası iktisat literatüründe çokça incelenmiş ve ancak çelişkili sonuçlara ulaşılmış oldukça tartışmalı bir konudur.

\begin{abstract}
This study fundamentally examines the effects of exchange rate volatility on export. The data consists of Turkey's five most prominent export partners Germany, France, Italy, United Kingdom, and USA during a period between January, 2002 and November 2014 and it has been analyzed by the ARDL bound testing approach. In addition, the effects of real exchange rate and industrial production index on export have been scrutinized. Findings show that contrary to theoritical expactations, exchange rate volatility has no statistically significal effect on export neither in short term or long term.
\end{abstract}

Keywords: Export, Exchange Rate Volatility, ARDL Bound Testing Approach

Bu çalışmanın amacı döviz kurundaki oynaklık ile ihracat arasında ilişkiyi araştıran ampirik tartışmalara Türkiye'nin en çok ihracat yaptığı beş ülke olan Almanya, Fransa, İtalya, İngiltere ve Amerika örneğiyle katkı sağlayabilmektir. Sözkonusu ülkelerin Ocak 2002 - Kasım 2014 dönemi verileri, ARDL Sınır Testi Yaklaşımı ile analiz edilmiştir. Döviz kuru oynaklığı Almanya, Fransa ve İtalya için Avro, İngiltere için İngiliz Sterlini, Amerika Birleşik Devletleri için de Amerikan Doları ile ölçülmüştür. Ayrıca reel döviz kuru ve ihracat yapılan ülkelerin endüstriyel üretim endeksinin de ihracata etkisi incelenmiştir. Ne kısa ne de uzun dönemde döviz kuru oynaklığı ile ihracat arasından anlamlı bir ilişki bulunamamıştır. Uzun dönemde ekonomik aktivite göstergesi olan endüstriyel üretim endeksinin sadece Almanya'ya ilişkin modelde ihracat üzerinde istatistiksel olarak anlamlı bir etkisi söz konusudur.

Son olarak çalışmaya konu 5 ülkenin sadece üçünde eşbütünleşme ilişkisinin varlığı sonucuna ulaşılmıştır. Bunlar Almanya, İtalya ve Fransa olup bu ülkeler için hata düzeltme modellerinden elde edilen 
sonuçlara göre kısa dönem dengeden sapmaların yaklaşık olarak Almanya ve İtalya için 2 ay ve Fransa için ise 2,5 ay gibi bir sürede tekrar dengeye geldiği bulunmuştur.

Çalışmada toplam inracat yerine en çok ihracat yapılan beş ülkenin analize dahil edilmesi, oynaklığın döviz sepetine göre değil ihracat yapılan ülkelerin döviz kurundaki değişimler ile tahmin edilmesi ve döviz kuru oynaklığının ihracat üzerinde beklenilen aksine anlamlı bir etkisinin olmaması ile ilgili bulgulara ulaşılması çalışmayı literatürdeki Türkiye üzerinde yapılan çalışmalardan farklı kılmaktadır.

Çalışmanın birinci bölümünde literatür kısaca özetlenmiş, ikinci bölümünde model tanıtılmış, üçüncü bölümde ulaşılan sonuçlar raporlanmış ve son bölümde sonuçlar tartışılmıştır.

\section{LITERATÜR}

Döviz kurunun iktisatçıları endişelendirecek kadar dalgalı bir yapıya sahip olmasının temel nedenlerinden biri uluslararası döviz piyasasının hiç kapanmayan, yedi gün yirmi dört saat, dünya çapında alım satımın yapılabildiği bir piyasa yapısına sahip olmasıdır (Sengupta \& Sfejr, 1997). Arz ve talebin sürekli değiştiği bu piyasada öngörüde bulunmak da bir o kadar zordur. Bu değişkenlik, belirsizliği ve riski ortaya çıkarmaktadır. Risk ile karşı karşıya kalan karar vericiler ya riskten kaçınacaklar ya da riski göze alacaklardır. Eğer riskten kaçınmayı tercih ederlerse ki literatür çoğunluğun böyle davrandığı göstermektedir, ya dış ticareti iç ticaret ile ikame edecekler ya da kur riskinden korunma yani hedging yöntemlerine başvuracaklardır. Doğal olarak dış ticareti iç ticaret ile ikame ederlerse ihracat ve ithalat bundan olumsuz etkilenecektir. Hedging yöntemlerine başvururlarsa dış ticaretten vazgeçmeden de riskten kaçınmış olacaklardır ki bu durumda döviz kurundaki oynaklık dış ticaretin temel belirleyicilerinden biri olarak çıkmayacaktır. Eğer riski göze alırlarsa yani kurdaki oynaklığa rağmen dış ticaretlerine devam ederlerse riske girdikleri ölçüde ya çok büyük bir kazanç elde edecek ya çok ciddi zararlarla karşı karşıya kalacaklar ya da herhangi bir anlamlı etki ile karşılaşmayacaklardır. Döviz kuru oynaklığının karar vericilerinin tercihlerini etkileyerek yaratabileceği bu farklı sonuçlar Şekil 1'de özetlenmeye çalışılmıştır.

Şüphesiz Şekil 1, tedarik zinciri içerisinde yer alan firmaların kısa dönemde yaşayabileceği olası durumları göstermektedir. Eğer anlamlı etkiler gerçekleşirse döviz kuru oynaklığı orta vadede ödemeler dengesini dolayısıyla tüm ekonomiyi etkileyebilecektir. Tedarik zincirleriyle tüm ülke ekonomilerinin birbirine eklemlendiği günümüz piyasa yapısı düşünüldüğünde döviz kuru oynaklığının küresel anlamda uzun dönemli yatırım, üretim, satış ve pazarlama kararlarını olumsuz etkileyebileceği söylenebilir.

Literatür incelendiğinde sermayenin küreselleşmesi ile birlikte özellikle 1980 sonrasında döviz kuru oynaklığı üzerine çok sayıda çalışma yapıldığı görülmektedir. Birçok çalışmada (Akhtar \& Hilton, 1984; Arize, Osang, \& Slottje, 2000, 2008; Chit, Rizov, \& Willenbockel, 2010; Chit, 2008; Chou, 2000; Coes, 1981; Cushman, 1983, 1986; Doğanlar, 2002; Kenen \& Rodrik, 1986; Koray \& Lastrapes, 1989; Sauer \& Bohara, 2001; Tang, 2014; Thursby \& Thursby, 1987) kurdaki oynaklığın riskleri artırması nedeniyle, riskten kaçınan ekonomik birimlerin dış ticaret yerine ülke içi ticarete yöneldiği ve bu durumun dış ticareti olumsuz etkilediği sonucuna ulaşılmıştır.

Döviz kurundaki oynaklığın dış ticareti olumsuz etkileyeceğinin savunan çalışmalardan biri olan Chowdhury (1993) döviz kuru oynaklığının G-7 ülkelerinin dış ticaretleri üzerine etkisini incelemiştir. Döviz kuru oynaklığının ihracat üzerinde olumsuz yönde bir etkisini olduğunu bulmuştur. Riskten kaçınmak isteyen ekonomik birimler döviz kurundaki belirsizlik karşısında ekonomik aktivitelerini azaltmakta, fiyatlarını değiştirmekte ya da kur oynaklığının zararlı etkilerinden kurtulmak için müşterilerini ya da tedarikçilerini değiştirmektedirler. Böylece finansal bir dalgalanma bölüşümde bir dalgalanmaya neden olmakta ekonominin geneline yayılmaktadır.

Poon \& Granger (2003) ekonominin kırılganlığının yüksek olduğu dönemlerde finansal oynaklığın ekonomi üzerinde daha önemli bir etkiye sahip olduğunu vurgulayarak literatürdeki çelişkili sonuçların varlık nedenine bir ölçüde ışık tutmaktadır. Oynaklığın yarattığı belirsizlik ekonomik kırılganlıkla birleştiğinde etki daha güçlü olmaktadır. Özellikle hedging uygulamaları için finans piyasaları yeterince olgunlaşmamış azgelişmiş ve gelişmekte olan ülkelerde kırılganlık nispi olarak daha fazla olacağından, bu ülkelerde olumsuz etkiler yaratması daha muhtemel gözükmektedir. Bu nedenle olsa gerek döviz kuru gelişmekte olan ülkeler için karar 
vericilerin gittikçe daha fazla önem verdiği bir gösterge haline gelmiş ve döviz kuru oynaklığı ise uluslararası yatırım kararlarında en önemli unsurlar arasında sayılmaya başlanmıştır (Kamal, Kama, Haq, Ghani, \& Khan, 2012).

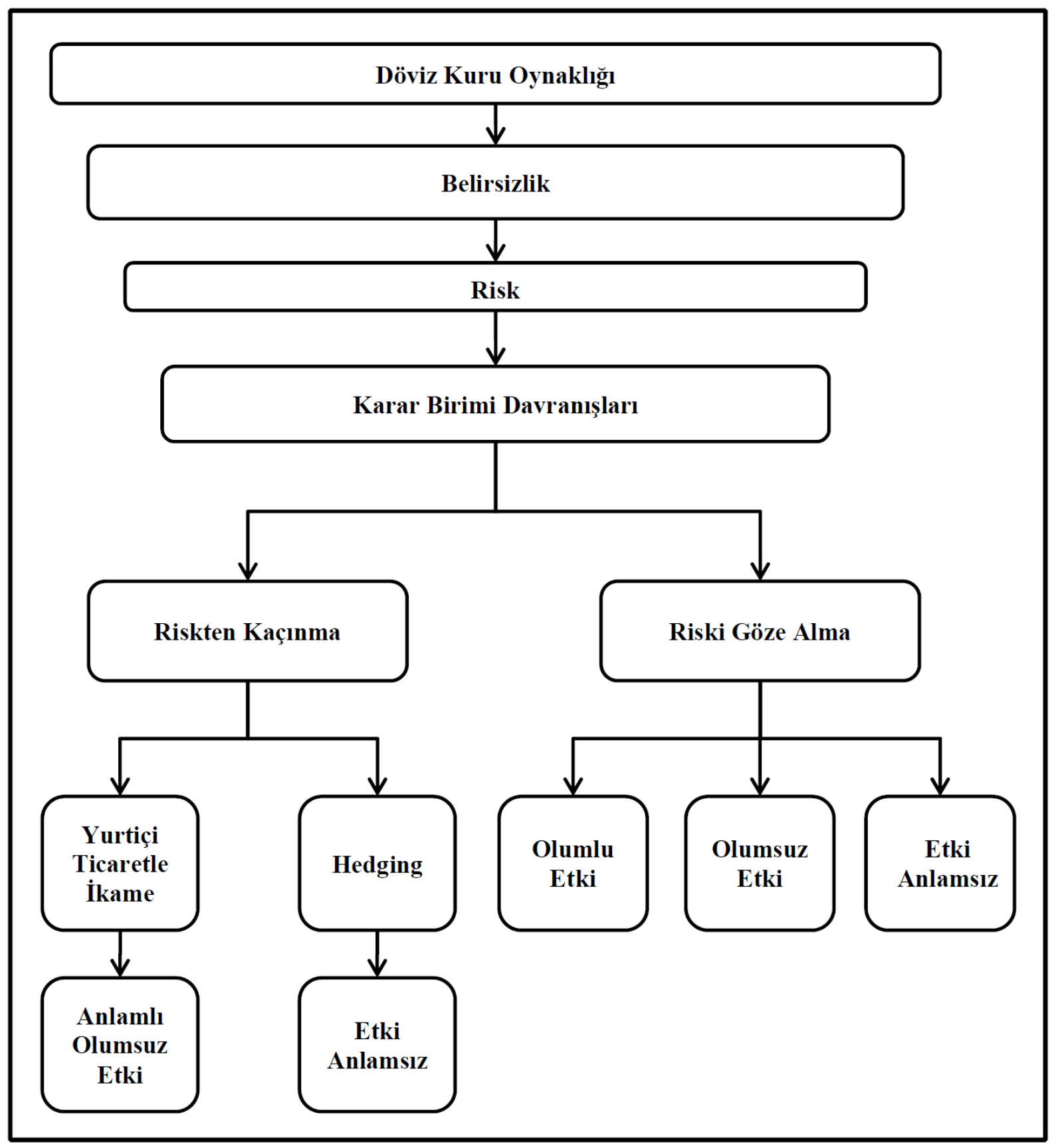

Şekil 1: Döviz Kuru Oynaklığının Davranışsal Etkileri

$\mathrm{Bu}$ noktada literatürde finansal gelişmişlikle döviz kuru oynaklığının ihracat üzerindeki etkisi arasında bir ilişki olup olmadığını araştıran çalışmalar karşımıza çıkmaktadır. Chit \& Judge (2011) beş gelişen Doğu Asya ülkesi için (Çin, Endonezya, Malezya, Filipinler ve Tayland) döviz kuru oynaklığının ihracat üzerindeki etkisinde finansal sektörün gelişmişliğinin rolünü incelemiştir. Chit \& Judge (2011)'e göre döviz kuru oynaklığının ihracata etkisi finansal sektörün gelişmişlik düzeyine bağlı olarak değişiklik göstermektedir. Finansal olarak daha az gelişmiş ülkelerin ihracatı, kur oynaklığından daha 
fazla olumsuz olarak etkilenmektedir. Çünkü hedging uygulamalarından yeterince yararlanamamaktadırlar.

Clark (1973) ve Kawai \& Zilcha (1986) hedging uygulamaları sayesinde döviz kuru oynaklığının ticaret üzerindeki olumsuz etkisinin zayıfladığını savunmaktadır. Finansal piyasalar yeterince gelişmemiş olmasa bile firmalar eğer kur riskinden korunma araçlarını kullanma fırsatına sahipse ihracatları oynaklıktan etkilenmemektedir (Broll, 1997). Likidite sıkıntısı ihracatçı ülkeler için finansal sektör gelişmişliğinin bir göstergesi olarak kabul edilmekte ve bunun da firmaların ihracat performansları üzerinde önemli bir etkisi olduğu savunulmaktadır (Chaney, 2005; Dekle \& Ryoo, 2007). Özet olarak Şekil 1'de görüldüğü gibi döviz kuru oynaklığı bir belirsizlik yaratmaktadır. Eğer firmalar bu belirsizliği ortadan kaldıracak finansal araçlara sahip bir piyasa yapısı içerisinde iseler ihracatlarının döviz kuru oynaklığından etkilenmediği düşünülmektedir.

Ülkelerin ekonomik büyüklüklerinin döviz kuru oynaklığının ihracata etkisinde rolünü inceleyen Huchet-Bourdon ve Korinek (2011) Çin, Avrupa ve Amerika Birleşik Devletleri için tarım ve imalat sanayi sektöründe ilişkiyi test etmiştir. Çalışma sonuçlarına göre döviz kuru oynaklığı analiz edilen büyük ekonomiler için çok güçlü bir belirleyici olarak çıkmamıştır. Ayrıca etkinin büyüklüğü tarımda sanayiden daha fazladır. Bunun nedenini tarımda sanayiden daha kolay tedarikçi değiştirmenin mümkün olmasına bir ölçüde tarımdaki homojeniteye bağlamaktadırlar.

Literatürde incelenen bir başka husus da oynaklığın şiddetidir. Eğer döviz kuru oynaklığı beklenmedik bir şekilde ortaya çıkıyorsa uluslararası ticarete etkisinin yıkıcı olacağı savunulmaktadır. Bu düşüncenin altında yatan neden, döviz kurundaki beklenmedik değişimlerin yaratacağı belirsizlik ve yeni duruma uyum maliyetleri nedeniyle dış ticaretin doğrudan düşmesidir (Clark, 1973; Ethier, 1973; Hooper \& Kohlhagen, 1978). Sengupta \& Sfejr (1997) ise bu doğrudan etkinin nedeni olarak oynaklığın şiddeti ile yatırımcıların bir ülkeye güveni arasında ters orantı olmasını göstermektedir. Oynaklığı kırılganlığın sinyali olarak algılayan ekonomik karar vericiler yatırımları ve ticari faaliyetlerini bu tür olumsuz sinyaller aldıkları ülkelerden daha güvenli ülkelere kaydırmaktadırlar.

Döviz kurundaki oynaklığın dış ticarete etkisini inceleyen çalışmalardan bir kısmı ticaret yapılan ülke sayısı ve ticarete konu olan ürün çeşitliliğini incelemiş ve döviz kurundaki oynaklığın yaygın ticarete (extensive margin of trade) etkisini ölçmeye çalışmışlardır (Alessandria, Kaboski \& Midrigan, 2008; Alessandria, Pratap \& Yue, 2014; Bergin \& Lin, 2012; Bernard, Jensen, Redding \& Schott, 2009; Naknoi, 2015). Başka bir ifadeyle döviz kurundaki dalgalanmanın, ihraç ürünü çeşitliliğini ve ihracat yapılan ülke sayısını nasıl etkilediğini incelemişlerdir. Araştırma sonuçları göstermiştir ki döviz kurundaki dalgalanmaları giderecek anlaşmalar veya döviz kuru riskinden koruyacak önlemler alındığında yaygın ticaret etkilenmemektedir aksi takdirde hem ihracatı yapılan ürün çeşitliliği hem de ihracat yapılan ülke açısından bir daralma söz konusu olmaktadır.

Hsu ve Chiang (2011) döviz kuru oynaklığı ile ihracat ilişkisine, ticaret yapılan ülkelerle söz konusu ülke arasında nispi kişi başı gayrisafi yurtiçi hâsıla farklılığı açısından bakmıştır. Araştırma sonuçlarına göre döviz kuru oynaklığı Amerika Birleşik Devletlerinin ticaret yaptığı ülkelerden nispi olarak daha yüksek kişi başı gayrisafi yurtiçi hasılaya sahip ülkelere ihracatı azaltırken, daha düşük kişi başı gayrisafi yurtiçi hasılaya sahip olan ülkelere ihracatını artırmaktadır.

Döviz kurundaki oynaklığın olumsuz etkileri olduğunu savunan çalışma sayısı fazla da olsa olumlu etkileri olduğunu savunan çalışmalarda (Asseery \& Peel, 1991; Franke, 1991; Giovannini, 1988; Sercu \& Vanhulle, 1992) bulunmaktadır. Bu çalışmalar kurdaki oynaklığın dış ticareti olumlu yönde etkilediği ile ilgili bulgulara ulaşmışlardır. Franke (1991) geliştirdiği modelle firmaların yurtdışı piyasadan çıkışla ilgili kararlarını vermeden önce çıkışın neden olacağı zararı değerlendirdiklerini ve oynaklığın bu çıkışı geciktirdiğini söylemektedir. Başka bir ifadeyle oynaklık dış ticaret piyasasındaki firma sayısının azalmasını engellemektedir (Asseery \& Peel, 1991).

Diğer taraftan Broll \& Eckwert (1999), Dellas \& Zilberfarb (1993) ve Grauwe (1988) döviz kurundaki oynaklığın ihracat üzerindeki karşılıklı iki etkiyle açıklamaya çalışmışlar. Bu çalışmalar kurdaki oynaklığın ihracatı hem olumlu hem de olumsuz olarak etkileyebileceğini, gelir ve ikame etkilerinden hangisi büyükse ona göre bir etkinin oluşacağını savunmaktadır. Riskten kaçınan firmaların döviz kuru oynaklığı ile karşılaştıklarında, ikame etkisi ile olası gelir kayıplarını engellemek ve gelirlerini sağlamlaştırmak adına ihracatlarını artırırken 
(olumlu etki), artan belirsizliğin gelir etkisi ile ticareti azaltacağını (olumsuz etki) savunmaktadır. Bazı ampirik çalışmalar (Bahmani-Oskooee \& Hegerty, 2007; McKenzie, 1999) bu çift yönlü ilişkiyi destekler sonuçlar bulmuştur.

Son olarak literatürde yine Şekil 1 de özetlenmeye çalışılan nedenlerle döviz kuru oynaklığı ile ticari akımlar arasında anlamlı bir ilişkinin olmadığını savunan çalışmalar da (Bailey, Tavlas \& Ulan, 1986; Gotur, 1985) bulunmaktadır. Bu çalışmalara göre döviz kuru oynaklığı, dış ticaretin belirleyicisi olarak kabul edilebilecek ölçüde anlamlı bir etki yaratmamakta ve istatistiki olarak anlamlı bir ilişki bulunmamaktadır.

Döviz kuru oynaklığı ihracat ilişkisini Türkiye örneğinde inceleyen bazı çalışmalar Tablo 1'de özetlenmeye çalışıımıştır. Tabloda da görüldüğü üzere yapılan çalışmaların çoğu Türkiye örneğinde de oynaklığın ihracatı olumsuz etkileyeceği yönündedir.

Coric \& Pugh (2010) söz konusu ilişkiyi araştıran çalışmaları derleyerek yaptığı meta-regresyon analizinde 58 çalışmanın 33'ünde döviz kurundaki dalgalanmanın uluslararası ticaret üzerindeki etkisinin olumsuz olduğunu gözlemlemiştir. Bununla birlikte sonuçların oldukça duruma bağlı olarak değiştiğini de kabul etmektedir. Incelenen tüm çalışmalardaki ilişki gücünün kur oynaklığının dış ticareti olumlu veya olumsuz etkileyeceği ile ilgili bir genelleme yapmak için yeterli sağlamlığa sahip olmadığı vurgulamaktadır. Sonuç olarak Coric \& Pugh (2010)'un meta analizi çalışmasında da vurguladığı gibi çok çelişkili bulguların yer aldığı literatürde söz konusu ilişkinin yönü ile ilgili net bir şey söylemek mümkün değildir.

Tablo 1: Döviz Kuru Oynaklığı İhracat İlişkisini Türkiye Örneğinde İnceleyen Bazı Çalışmalar

\begin{tabular}{lccc}
\hline Çalışma & Dönem & Yöntem & Ulaşılan Sonuç \\
\hline Özbay (1999) & $1988-1997$ & Regresyon Analizi & Olumsuz etki \\
\hline Vergil (2002) & $1990-2000$ & Eşbütünleşme & Olumsuz etki \\
\hline Doğanlar (2002) & $1980-1996$ & Eşbütünleşme & Olumsuz etki \\
\hline Acaravcı \& Öztürk (2002) & $1989-2002$ & Eşbütünleşme & Olumsuz etki \\
\hline Kasman (2003) & $1989-2002$ & Eşbütünleşme & Olumsuz etki \\
\hline Saatcioğlu ve Karaca (2004) & $1981-2000$ & Eşbütünleşme & Olumsuz etki \\
\hline Rey (2006) & $1970-2002$ & Eşbütünleşme & Olumsuz etki \\
\hline Tarı ve Yıldırım (2009) & $1989-2007$ & Eşbütünleşme & Kısa dönemde etki anlamsız, uzun \\
dönemde olumsuz etki
\end{tabular}

\section{METODOLOJI}

Bu çalışma da Türkiye için ihracat ile döviz kuru oynaklığı arasındaki ilişki Türkiye'nin en çok ihracat yaptığı beş ülkeye ilişkin veriler kullanılarak incelenmiştir. Ancak bu inceleme yapılırken, Türkiye'nin en çok ihracat yaptığı ikinci ülke olan Irak'a ilişkin veri bulunamadığından incelemenin dışında bırakılmış onun yerine Türkiye'nin en çok ihracat yaptığı altıncı ülke olan Amerika Birleşik
Devletleri modele dâhil edilmiştir. Diğer ülkeler ise Almanya, Fransa, İtalya ve İngiltere'dir. Çalışma da Ocak 2002 - Kasım 2014 dönemine ilişkin aylık frekansta veri seti kullanılmıştır. Döviz kuru oynaklığı hesaplanırken önceki 12 aylık gözlem kullanılması, 12 aylık bir gözlem kaybına neden olmaktadır. Bu nedenle inceleme dönemi Ocak 2003 - Kasım 2014'ü kapsamaktadır. Çalışma da döviz kuru oynaklığının ölçümünde Almanya, İtalya ve Fransa için Avro, 
İngiltere için İngiliz Sterlini ve Amerika Birleşik Devletleri içinde Amerikan Doları kullanıımıştır.Veriler IMF, Türkiye İstatistik Enstitüsünün (TÜiK) ve Türkiye Cumhuriyet Merkez Bankasının veri tabanında elde edilmiştir. Reel ihracat verisi için TÜik veri tabanı kullanırken, döviz kuru verisi için Türkiye Cumhuriyet Merkez Bankasının veri tabanı kullanıımıştır.

Çalışmada kullanılan model Denklem (1) de gösterilmiştir.

$$
\operatorname{LREXP}_{i, t}=\beta_{0}+\beta_{1} L_{I P I_{i, t}}+\beta_{2} L R E X R_{i, t}+\beta_{3} L V_{i, t}+\varepsilon_{i, t}
$$

Denklem (1) de i ülkeyi $t$ ise zamanı ifade etmektedir. Analiz edilen beş ülkenin her biri için ayrı bir regresyon söz konusudur. Ayrıca Denklem (1)'de;

LREXP: Doğal logaritması alınmış reel ihracat

LIPI: Doğal logaritması alınmış, mevsimsellikten arındırılmış endüstriyel üretim endeksi

LREXR: Doğal logaritması alınmış reel döviz kuru

$L V$ : Doğal logaritması alınmış döviz kuru oynaklığı değişkenini ifade etmektedir.

Denklem (1)'deki ilk değişken olan endüstriyel üretim endeksi Türkiye'nin ihracat yaptığı ülkelerin gelir düzeyinin ihracat üzerindeki etkisinin ölçmek içindir. Aslında gayri safi yurtiçi hâsıla ile ölçülmesi gereken bu ilişki gayrisafi yurtiçi hasılaya ilişkin aylık veri bulunmadığı için endüstriyel üretim endeksi ile ölçülmeye çalışılmıştır. Böylece ihracat yapılan ülkedeki ekonomik aktivenin ihracat üzerindeki etkisi incelenebilecektir. İhracat yapılan ülkedeki ekonomik aktivite artışının ihracatı olumlu yönde etkilemesi ( $\beta_{1}>0$ ) beklenmektedir.

Denklem (1)'deki ikinci değişken reel döviz kurudur. Denklem (2) ile bir ülke için reel döviz kurunun nasıl hesaplandığı gösterilmiştir. Reel döviz kurundaki artışın ihracatı olumlu yönde etkilemesi $\left(\beta_{2}>0\right)$ beklenmektedir.

$$
R E X R=E X R \frac{P_{F}}{P_{H}}
$$

Denklem (2) deki;

REXR: Reel döviz kuru

EXR: Nominal döviz kuru

$P_{F}$ :Yabancı ülke tüketici fiyat endeksi

$P_{H}:$ Ülke içi tüketici fiyat endeksi

Denklem (1)'deki son değişken döviz kuru oynaklığıdır ki bu çalışmada asıl incelenmek istenen değişken budur. Literatür özetinde açıklandığı üzere döviz kuru oynaklığının ihracat üzerindeki etkisi çok tartışmalıdır. Çalışmaların çoğunda olumsuz bir etki olduğu savunulsa da aksi yönde bulgularda mevcuttur.

Döviz kuru oynaklığı aynen Chowdurry (1993)'te tanımlandığı gibi Denklem (3)'e göre hesaplanmıştır.

$$
V_{t}=\left[\frac{1}{m} \sum_{i=1}^{m}\left(\log R E X R_{t+i-1}-\log R E X R_{t+i-2}\right)^{2}\right]^{1 / 2}
$$

Burada logREXR reel döviz kurunun doğal logaritmasını göstermektedir. 2003:1 dönemine ait oynaklık 2002:2 ile 2003:1 arasındaki aylık getirilerin ortalaması alınarak elde edilmiştir. Burada log ifadesi doğal logaritmayı ve parantez içindeki ifade de aylık getiriyi ifade etmektedir. Aylık getiriler hesaplanırken birinci gözlem kaybedilmiştir ve birinci hareketli ortalama hesaplanırken 11 tane gözlem kaybı söz konusu olmuştur. Dolayısıyla $m=12$ hareketli ortalama alınırken 2002:1 ile 2002:12 arasındaki 12 gözlem kaybı söz konusu olmuştur.
Denklem (1)'deki modelin uygulanması sadece uzun dönem ilişkiyi sunmaktadır, hem uzun dönem hem de kısa dönem ilişkileri incelemek için Denklem (4) kullanılmıştır. Bu ikinci model ile dinamik düzeltme mekanizması (Dynamic Adjustment Mechanism) uygulanarak uzun dönem etkiler ve kısa dönem etkiler birlikte incelenmiştir. Modelde BahmaniOskooee \& Hegerty (2009) ve Pesaran, Shin, \& Smith (2001) ARDL Sınır Testi yaklaşımlarından istifade edilmiştir. Sınır testi çerçevesinde model Denklem (4)'te gösterilmiştir. 


$$
\begin{aligned}
& \Delta \operatorname{LREXP}_{i, t}=\alpha_{0}+\sum_{k=1}^{n 1} \alpha_{i, 1 k} \Delta L R E X P_{i, t-k}+\sum_{k=0}^{n 2} \alpha_{i, 2 k} \Delta L I P I_{i, t-k} \\
& +\sum_{k=0}^{n 3} \alpha_{i, 3 k} \Delta L R E X R_{i, t \aleph k}+\sum_{k=0}^{n 4} \alpha_{i, 4 k} \Delta L V_{i, t}{ }_{k}{ }_{i, 0} L R E X P_{i, t} 1 \\
& +\gamma_{1} L I P I_{i, t-k}+\gamma_{i, 2} L R E X R_{i, t-1}+\gamma_{i, 3} L V_{i, t-1}+\Psi_{i t}
\end{aligned}
$$

Denklem (4) hem düzey değişkenlerini hem de fark değişkenlerini barındırmaktadır. Düzey değişkenleri uzun dönem ilişkilere ilişkin bulgular sunarken, fark değişkenleri kısa dönem ilişsilere yönelik bulgular sunmaktadır. $\Delta$ birinci farkı göstermektedir ve model hata düzeltme modeli olarak adlandırılmaktadır.

Düzey değişkenlerin gecikmeli değerlerine standart F testi uygulandıktan sonra Pesaran, Shin \& Smith (2001)'in tavsiye ettiği tablo değerlerini kullanarak uzun dönemli ilişkinin varlığı test edilmiştir. Eğer elde edilen Pesaran, Shin \& Smith (2001)'in sunduğu alt sınır değerlerinden küçük ise değişkenler 0 derecesinden bütünleşik oldukları, üst sınır değerinden büyük ise değişkenlerin birinci dereceden bütünleşik oldukları sonucuna ulaşılımıştır. Bu durumda öncesinden birim kök testleri yapmaya gerek yoktur. Bunun yanı sıra Denklem (4) bağımlı değişken üzerinde hem kısa dönem hem de uzun dönem etkilerin sonuçlarını sunmaktadır. Örneğin burada $\alpha_{i, 4 k}$ eğer istatistiksel olarak anlamlı ise döviz kurundaki oynaklığın ihracat üzerinde yarattığı kısa dönem etkinin varlığını ve büyüklüğünü göstermektedir ve uzun dönem etki ise $\gamma_{i, 3}$ parametresinin $\gamma_{i, 0}$ üzerine yapılan normalleştirme işlemi sonucu elde edilmektedir.

\section{BULGULAR}

Denklem (4) aylık veriler kullanılarak her bir ülke için ayrı ayrı hesaplanmıştır. Uygun gecikme uzunluğu Akaike Bilgi Kriteri (AIC) kullanılarak modele dâhil edilmiştir ve modeller LM testi ile otokorelasyon problemi, RESET testi ile spesifikasyon hatası ve CUSUM ve CUSUMSQ testleri ile de parametre stabiliteleri testi yapılarak kontrol edilmiştir. Modellerin uygun gecikme uzunluğu seçilirken en küçük AIC kriterine sahip olan seçilmiştir. Sonuç olarak Almanya için ARDL $(3,0,2,0)$, İngiltere için ARDL $(4,4,1,0)$, İtalya için ARDL $(3,1,1,0)$, Fransa için ARDL $(3,0,7,5)$ ve Amerika Birleşik Devletleri için ise ARDL
$(8,0,0,0)$ modelleri kullanılmıştır. Analizde kullanılan değişkenlerin betimleyici istatistikleri Tablo 2'de, birim kök test sonuçları Tablo 3'de sunulmuştur. Denklem (1), Denklem (4) ve uzun dönem ilişkinin varlığı durumunda Denklem (1)'den elde edilen hatalar kullanılarak Denklem (4)'ün Hata Düzeltme Modeli şeklinde tekrar hesaplanmasından tahmin edilen Hata Düzeltme Terimine ilişkin sonuçlar Tablo 4'de sunulmuştur. Yanı sıra Tablo 4'de ARDL sınır testi yaklaşımında standart olan hata tanı test sonuçları da mevcuttur. Takip eden Şekil 2'de ise sonuçları Tablo 4'de özet olarak verilmiş olan CUSUM ve CUSUMSQ grafikleri sunulmaktadır. Grafiklerden anlaşıldığı üzere tahmin edilen modeller stabildir.

Tablo 3'de görüldüğü gibi seviye düzeyinden yapılan birim kök testlerinden sadece İtalya'nın endüstriyel üretim endeksi (LIPI) hariç diğer tüm seriler için karışık sonuçlar elde edilmiştir. İtalya'nın endüstriyel üretim endeksi (LIPI) serisi ise seviye düzeyinden durağan çıkmamaktadır. Dolayısıyla tüm serilerin birinci farkını alarak tekrar birim kök testlerine başvurulmuştur.

Serilerin birinci farkları alındıktan sonra elde edilen birim kök test sonuçları yine Tablo 2'de yer almaktadır. Bu test sonuçlarına göre 4 seri hariç tüm serilerin birinci fark alındıktan sonra durağan olduğu sonucuna ulaşıımıştır. Almanya, İtalya ve Fransa'nın reel ihracat serileri (LREXP) ile Amerika Birleşik Devletlerine ait olan endüstriyel üretim endeksi serisi (LIPI) için karışık sonuçlar elde etmekle birlikte test sonuçları ağırlıklı olarak bu serilerin birinci fark alındıktan sonra durağan oldukları yönünde sonuç sunmaktadır. Dolayısıyla bu serilerin de I(1) olduklarını kabul edilmiştir. Sonuç olarak birinci fark alındıktan sonra tüm serilerin durağan olduğu bulgusuna ulaşılmıştır. 
Tablo 4'de kısa dönem oynaklık (volatilite) parametre hesapları ve uzun dönem ilişkiler sunulmuştur. Sonuç olarak Tablo 4 incelendiğinde, model belirleme esnasında kısa dönem için Almanya, İngiltere, İtalya ve Amerika Birleşik Devletleri için herhangi bir oynaklık - ihracat ilişkisi elde edilememiştir. Yanı sıra sadece Fransa için kısa dönem ilişkiler elde edilmesine rağmen 4'üncü gecikmeye ait parametre tahmini hariç tüm diğer parametre tahminleri istatistiksel olarak anlamsız bulunmuştur. Bunun anlamı 4 dönem önce Euro döviz kurunun oynaklığında meydana gelen \%10'luk bir artış Fransa'ya olan bugünkü ihracatı \%2.6 azaltmaktadır.
Bir sonraki aşamada değişkenler arasında uzun dönem denge ilişkisinin varlığı ya da diğer bir deyişle eşbütünleşmenin varlığı incelenmiştir. Tablo 4'de sınır testi $\mathrm{F}$ başlıkları altında bu sonuçlar mevcuttur. Bu sonuçlara göre Almanya, İtalya ve Fransa için uzun dönem ilişki saptanmakla birlikte, İngiltere ve Amerika Birleşik Devletleri için istatistiksel olarak anlamlı bir ilişki söz konusu değildir. Dolayısıyla sadece bu üç ülkeye ait uzun dönem parametre tahminleri Tablo 4'de yer almaktadır. Bu sonuçlara göre oynaklığın kısa döneme benzer şekilde uzun dönem de istatistiksel olarak anlamlı bir etkisi söz konusu olmadığı sonucuna ulaşılmıştır. 


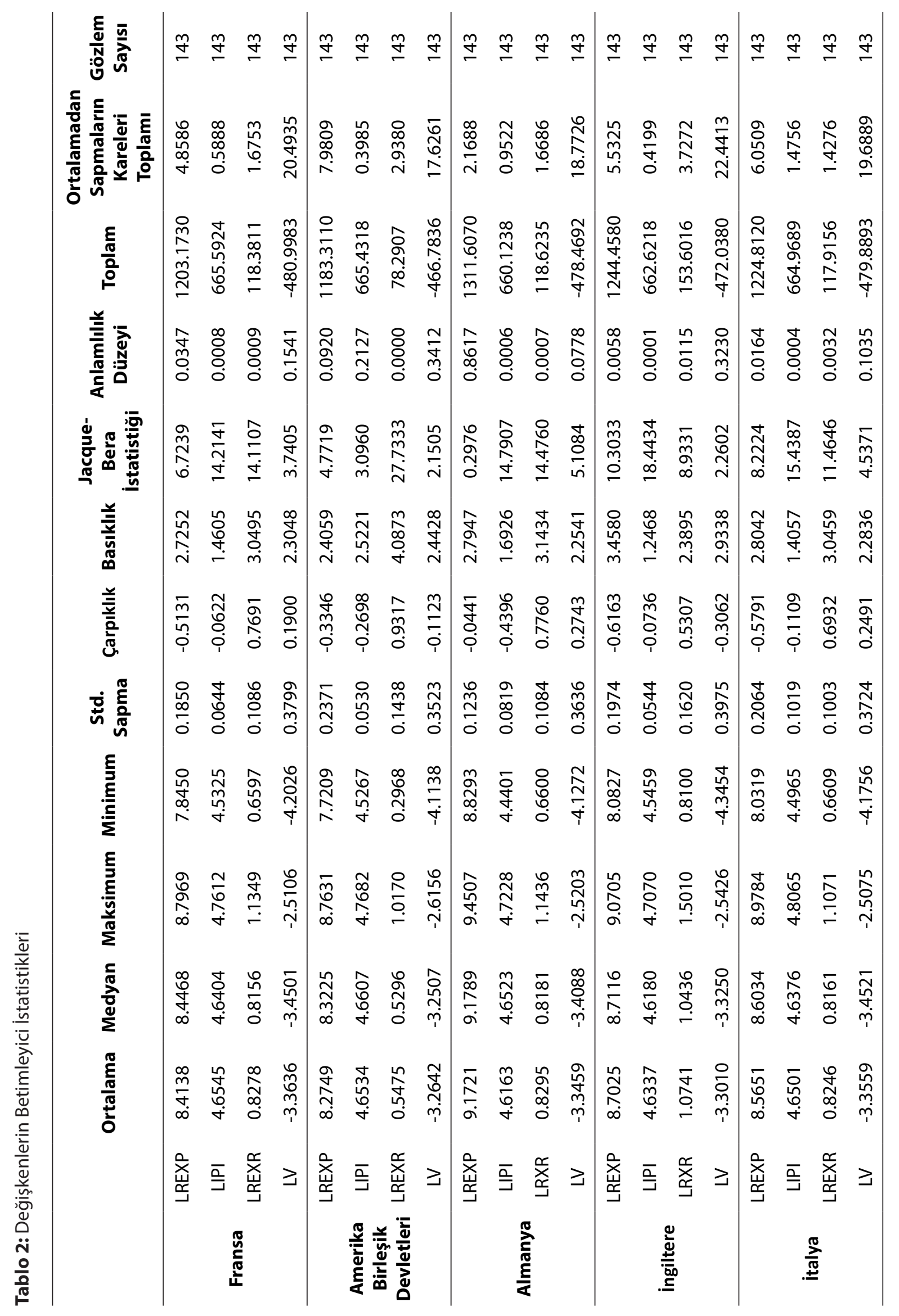


Tablo 3: Birim Kök Testi Sonuçları

\begin{tabular}{|c|c|c|c|c|c|c|c|}
\hline \multirow{3}{*}{ Ülkeler } & \multirow[b]{3}{*}{ Seriler } & \multicolumn{6}{|c|}{ Seviye } \\
\hline & & \multicolumn{2}{|c|}{ ADF } & \multicolumn{2}{|c|}{ PP } & \multicolumn{2}{|c|}{ KPSS } \\
\hline & & Sabit & $\begin{array}{l}\text { Sabit + } \\
\text { Trend }\end{array}$ & Sabit & $\begin{array}{l}\text { Sabit + } \\
\text { Trend }\end{array}$ & Sabit & $\begin{array}{r}\text { Sabit + } \\
\text { Trend }\end{array}$ \\
\hline \multirow{4}{*}{ Almanya } & LREXP & -1.84 & -2.90 & $-8.44 * * *$ & $-10.86 * * *$ & $0.84^{* * *}$ & $0.15 * *$ \\
\hline & LIPI & -2.21 & -2.84 & -1.80 & -2.27 & $0.76 * * *$ & 0.10 \\
\hline & LREXR & $-3.02 * *$ & $-3.19 *$ & $-3.04 * *$ & $-3.25^{*}$ & $0.90 * * *$ & $0.24 * * *$ \\
\hline & LV & $-2.59 *$ & -2.94 & $-2.68^{*}$ & $-3.25^{*}$ & $0.97 * * *$ & 0.06 \\
\hline \multirow{4}{*}{ İngiltere } & LREXP & $-3.93 * * *$ & $-4.42 * * *$ & $-5.03 * * *$ & $-6.17 * * *$ & $0.62 * *$ & $0.14 *$ \\
\hline & LIPI & -0.92 & -2.22 & -0.87 & -2.27 & $1.17 * * *$ & $0.12 *$ \\
\hline & LREXR & $-2.68^{*}$ & -2.33 & $-2.68^{*}$ & -2.27 & $1.03^{* * *}$ & $0.31 * * *$ \\
\hline & LV & -2.51 & -2.68 & $-2.67^{*}$ & -2.98 & $0.77 * * *$ & 0.05 \\
\hline \multirow{4}{*}{ Italya } & LREXP & $-3.30 * *$ & -2.80 & $-8.02 * * *$ & $-8.22 * * *$ & 0.26 & $0.21 * *$ \\
\hline & LIPI & -1.22 & -2.65 & -0.91 & -2.21 & $1.08 * * *$ & $0.13 *$ \\
\hline & LREXR & $-3.09 * *$ & $-3.17 *$ & $-3.14 * *$ & $-3.25 *$ & $0.77 * * *$ & $0.24 * * *$ \\
\hline & LV & $-2.60 *$ & -2.93 & $-2.64^{*}$ & $-3.23 *$ & $0.96 * * *$ & 0.05 \\
\hline \multirow{4}{*}{ Fransa } & LREXP & -1.98 & $-3.43^{*}$ & $-5.97 * * *$ & $-8.26 * * *$ & $1.04^{* * *}$ & $0.30 * * *$ \\
\hline & LIPI & -1.34 & -2.47 & -1.23 & -2.28 & $0.96 * * *$ & 0.11 \\
\hline & LREXR & $-2.93 * *$ & $-3.16 *$ & $-2.96 * *$ & $-3.25 *$ & $0.93 * * *$ & $0.24 * * *$ \\
\hline & LV & -2.55 & -2.88 & $-2.59 *$ & $-3.18 *$ & $0.99 * * *$ & 0.06 \\
\hline \multirow{4}{*}{$\begin{array}{r}\text { Amerika } \\
\text { Birleşik } \\
\text { Devletleri }\end{array}$} & LREXP & $-2.65^{*}$ & -2.58 & $-4.20 * * *$ & $-4.18 * * *$ & $0.39 *$ & $0.32 * * *$ \\
\hline & LIPI & -2.00 & -2.28 & -0.98 & -1.32 & 0.32 & $0.16 * *$ \\
\hline & LREXR & $-3.39 * *$ & -2.96 & $-3.39 * *$ & -2.97 & $0.83 * * *$ & $0.32 * * *$ \\
\hline & LV & $-2.97 * *$ & $-3.19 *$ & $-3.14 * *$ & $-3.47 * *$ & $0.45^{*}$ & 0.08 \\
\hline & & \multicolumn{6}{|c|}{ Birinci Fark } \\
\hline \multirow{4}{*}{ Almanya } & LREXP & $-2.82^{*}$ & -2.81 & $-58.04 * * *$ & $-59.78 * * *$ & 0.33 & $0.21 * *$ \\
\hline & LIPI & $-4.50 * * *$ & $-4.49 * * *$ & $-12.58 * * *$ & $-12.54 * * *$ & 0.06 & 0.05 \\
\hline & LREXR & $-11.36 * * *$ & $-11.39 * * *$ & $-11.35^{* * *}$ & $-11.38 * * *$ & 0.11 & 0.03 \\
\hline & LV & $-11.35^{* * *}$ & $-11.33^{* * *}$ & $-11.35^{* * *}$ & $-11.33^{* * *}$ & 0.08 & 0.04 \\
\hline \multirow{4}{*}{ İngiltere } & LREXP & $-12.44 * * *$ & $-12.40 * * *$ & $-24.48 * * *$ & $-24.51 * * *$ & 0.10 & 0.08 \\
\hline & LIPI & $-13.54 * * *$ & $-13.49 * * *$ & $-13.46 * * *$ & $-13.41 * * *$ & 0.11 & 0.11 \\
\hline & LREXR & $-9.87 * * *$ & $-10.00 * * *$ & $-11.72 * * *$ & $-11.88 * * *$ & 0.23 & 0.03 \\
\hline & LV & $-11.77^{* * *}$ & $-11.75^{* * *}$ & $-11.77^{* * *}$ & $-11.75^{* * *}$ & 0.07 & 0.05 \\
\hline \multirow{4}{*}{ Italya } & LREXP & $-5.11 * * *$ & $-5.32 * * *$ & $-35.55^{* * *}$ & $-39.34 * * *$ & 0.19 & $0.14^{*}$ \\
\hline & LIPI & $-4.32 * * *$ & $-4.32 * * *$ & $-12.37 * * *$ & $-12.36 * * *$ & 0.07 & 0.06 \\
\hline & LREXR & $-11.22 * * *$ & $-11.24^{* * *}$ & $-11.20 * * *$ & $-11.22^{* * *}$ & 0.10 & 0.03 \\
\hline & LV & $-11.36 * * *$ & $-11.35^{* * *}$ & $-11.37 * * *$ & $-11.36 * * *$ & 0.08 & 0.04 \\
\hline \multirow{4}{*}{ Fransa } & LREXP & $-4.61 * * *$ & $-4.73 * * *$ & $-38.18 * * *$ & $-46.85 * * *$ & $0.37 *$ & $0.21 * *$ \\
\hline & LIPI & $-5.13 * * *$ & $-5.12 * * *$ & $-14.37 * * *$ & $-14.34 * * *$ & 0.08 & 0.07 \\
\hline & LREXR & $-11.19 * * *$ & $-11.21 * * *$ & $-11.17 * * *$ & $-11.19 * * *$ & 0.10 & 0.03 \\
\hline & LV & $-11.24 * * *$ & $-11.22 * * *$ & $-11.25^{* * *}$ & $-11.23 * * *$ & 0.08 & 0.04 \\
\hline \multirow{4}{*}{$\begin{array}{r}\text { Amerika } \\
\text { Birleşik } \\
\text { Devletleri }\end{array}$} & LREXP & $-20.02 * * *$ & $-19.98 * * *$ & $-28.90 * * *$ & $-35.34 * * *$ & 0.25 & $0.12^{\circ}$ \\
\hline & LIPI & $-2.73^{*}$ & -2.76 & $-10.46 * * *$ & $-10.51 * * *$ & 0.15 & 0.11 \\
\hline & LREXR & $-11.22 * * *$ & $-11.37 * * *$ & $-11.20 * * *$ & $-11.43 * * *$ & 0.29 & 0.04 \\
\hline & LV & $-12.13 * * *$ & $-12.09 * * *$ & $-12.13 * * *$ & $-12.09 * * *$ & 0.03 & 0.03 \\
\hline
\end{tabular}

Not: ${ }^{* *},{ }^{* *}$ ve * sırasıyla \%1, \%5 ve \%10 seviyesinde istatistiksel olarak anlamlılık düzeylerini göstermektedir. Ondalık kısım iki basamağa yuvarlanarak tabloda gösterilmiştir. • Bu test sonucu yuvarlamadan dolayı anlamlı gözükmekle birlikte istatistiksel olarak anlamsızdır, çünkü elde edilen KPSS istatistiği 0.118136 ( 0.12 olarak yuvarlanmıştır) olup ve bu değer \%10 anlamlılık düzeyinde tablo değeri olan 0.119 ile karşılaştırıldığında istatistiksel olarak anlamsız sonucuna ulaşılmaktadır. 


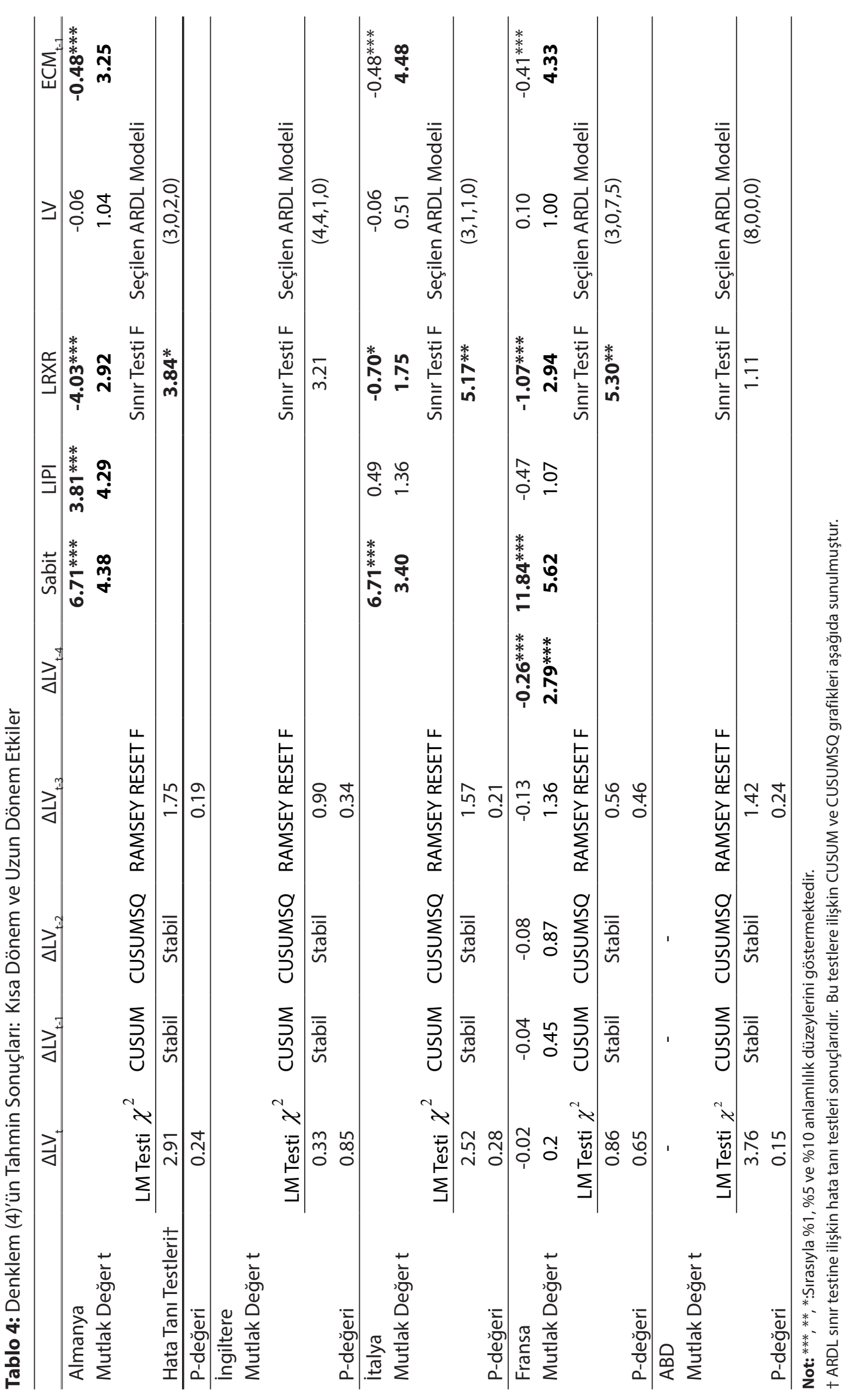


Şekil 2: CUSUM ve CUSUMSQ Grafikleri

\section{Almanya}
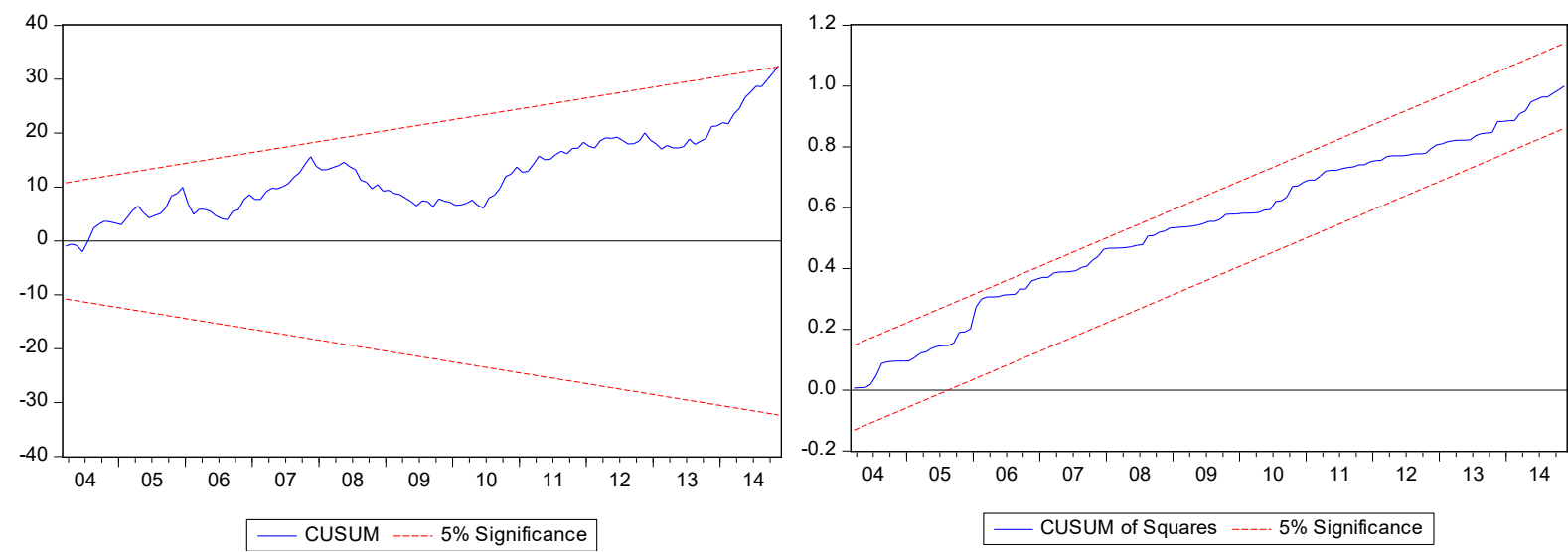

\section{Ingiltere}
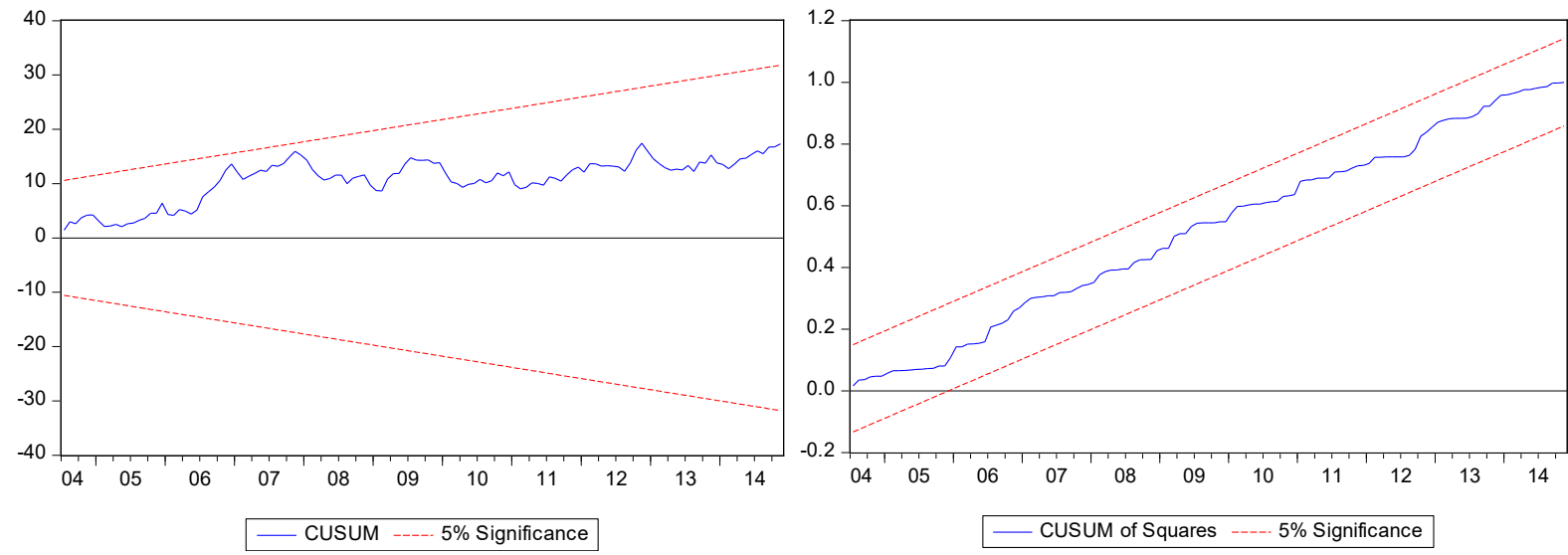

\section{İtalya}
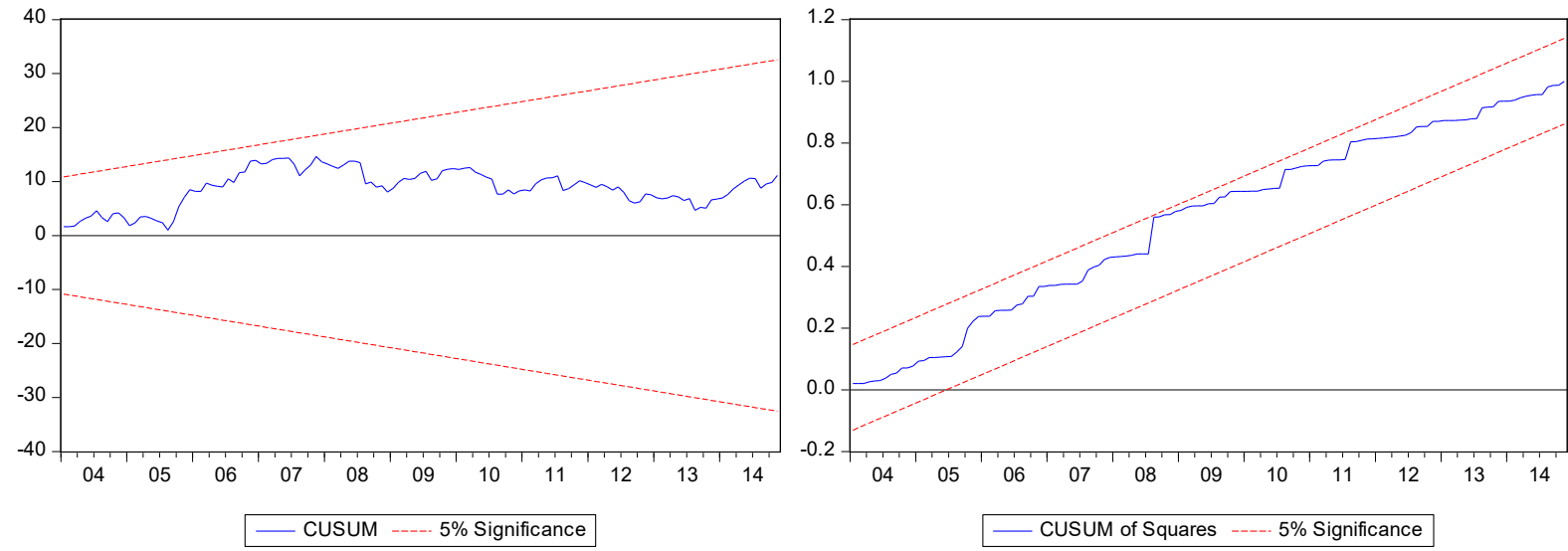


\section{Fransa}

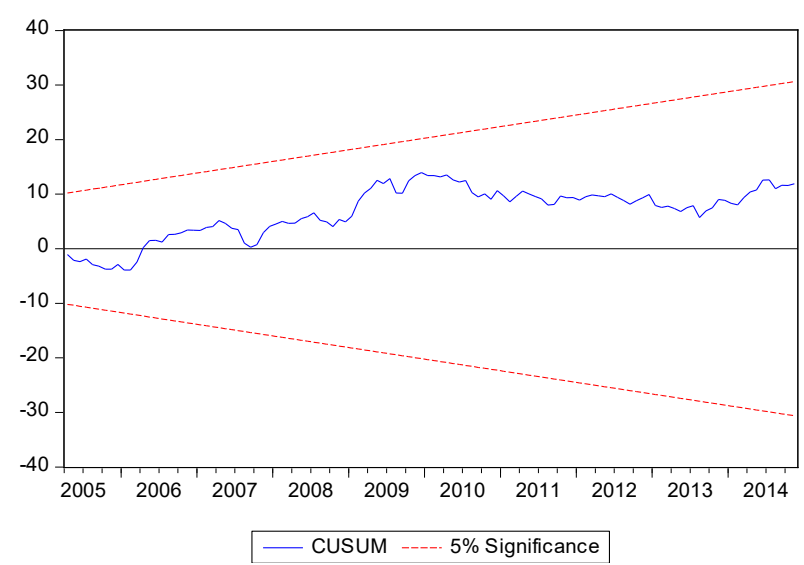

\section{Amerika Birleşik Devletleri}

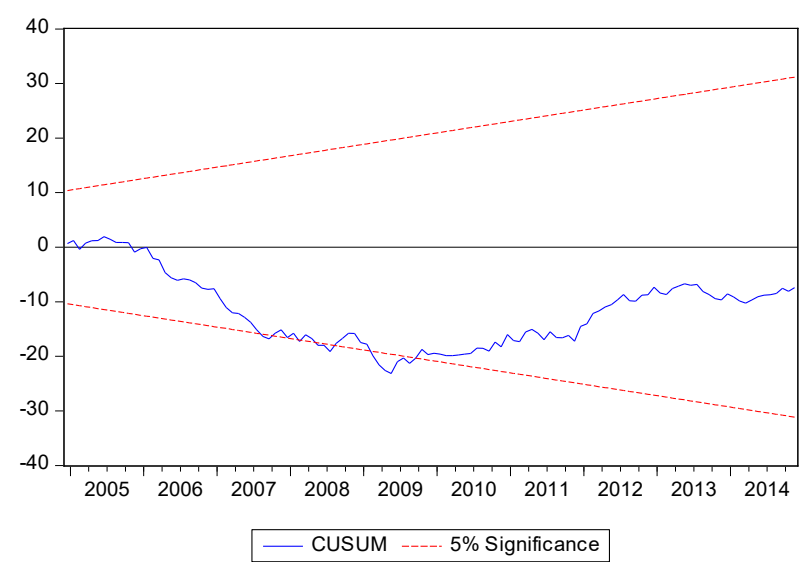

Diğer parametre tahminlerine bakılacak olursa Almanya'daki ekonomik aktivitede (LIPI'de) meydana gelen \%1'lik bir artış uzun dönem de Türkiye'nin Almanya'ya ihracatını yaklaşık \%3.81 artırmaktadır. Yine Almanya için reel döviz kurundaki \%1'lik artış ise Türkiye'nin Almanya'ya olan ihracatını uzun dönem de yaklaşık \%4.03 azaltmaktadır. İtalya için ise LIPI değişkenine ilişkin parametre tahmini oynaklığa benzer şekilde istatistiksel olarak anlamlı değildir. Fakat reel döviz kuru değişkenine (LRXR) ait parametre tahmini Almanya'da olduğu gibi istatistiksel olarak anlamlı olup reel döviz kurunda meydana gelen $\% 1$ 1'lik bir artış İtalya'ya olan ihracatı yaklaşık \%0.7 azalmaktadır. Fransa içinde İtalya'ya benzer bir sonuç söz konusudur, yine reel döviz kurunda meydana gelen \%1'lik bir artış Fransa'ya olan ihracatı yaklaşık \%1.07 azalmaktadır.

Değişkenlerin arasında uzun dönem ilişkinin söz konusu olduğu durumda Denklem (4) hata düzeltme modeline dönüştürülerek yeniden tahmin edilmiştir ve Tablo 4'ün son sütununda Hata Düzeltme Terimine
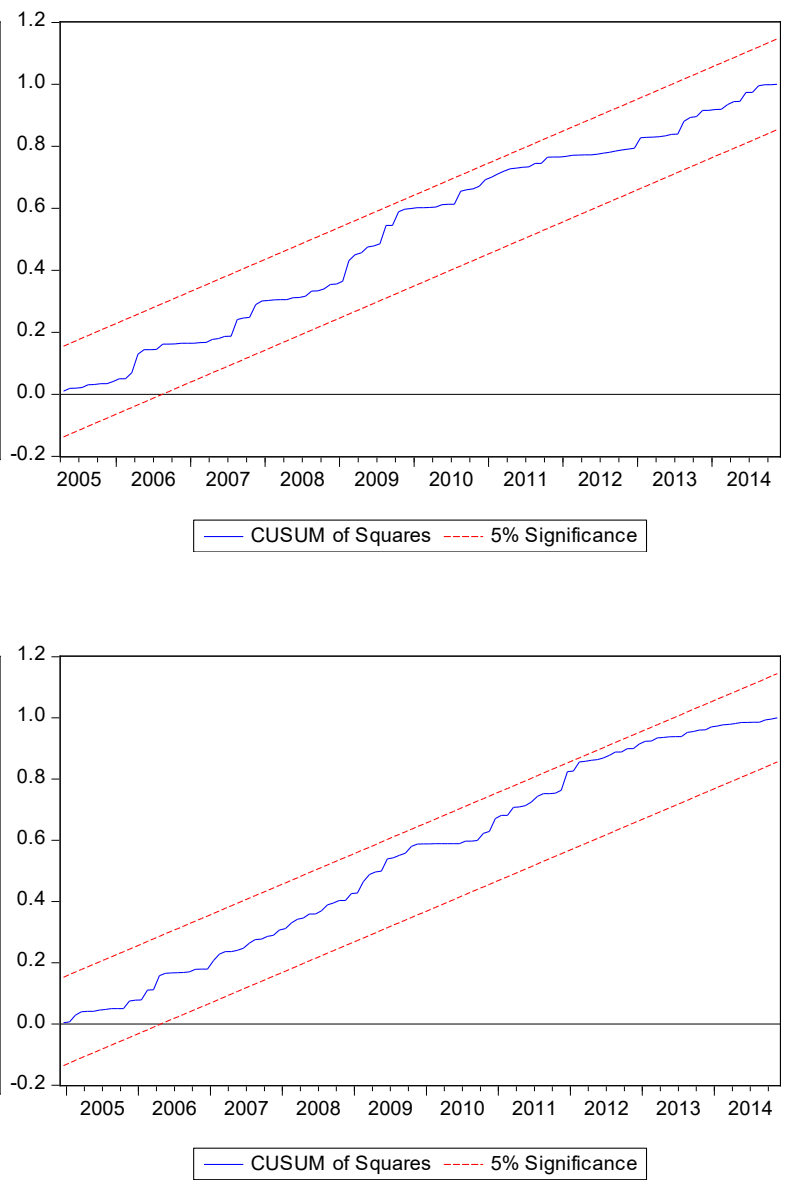

$\left(E C M_{t-1}\right)$ ilişkin tahminler yer almaktadır. Bu sonuçlara göre kısa dönemden uzun dönem dengeye dönüş Almanya ve İtalya için yaklaşık 2 ay iken, Fransa için yaklaşık 2.5 ay sürmektedir.

\section{SONUÇ VE DEĞERLENDIRME}

Bu çalışma sonucunda döviz kuru oynaklığının ihracat üzerinde olumsuz etkisi olduğu savunan çalışmaların (Akhtar \& Hilton, 1984; Arize et al., 2000, 2008; Chit et al., 2010; Chit, 2008; Chou, 2000; Coes, 1981; Cushman, 1983, 1986; Doğanlar, 2002; Kenen \& Rodrik, 1986; Koray \& Lastrapes, 1989; Sauer \& Bohara, 2001; Tang, 2014; Thursby \& Thursby, 1987) aksine anlamlı bir etkinin olmadığını savunan çalışmaların (Clark, 1973; Kawai \& Zilcha 1986; Bailey, Tavlas \& Ulan, 1986; Gotur, 1985; Balcılar vd. 2014) savlarını destekler nitelikte bir ampirik sonuca ulaşmıştır. Tablo 1'de yer alan ve döviz kuru oynaklığı ihracat ilişkisini Türkiye örneğinde inceleyen ve genel olarak oynaklığın etkisini olumsuz bulan çalışmaların aksine bu çalışma oynaklığın ihracat üzerinde etkisinin anlamlı olmadığına yönelik sonuçlar elde etmiştir. 
Bu çalışmada Türkiye örneğinde döviz kurundaki oynaklığın ihracat üzerindeki etkisinin anlamlı olmaması Clark (1973) ve Kawai \& Zilcha (1986)'nın dikkat çektiği kur riskinden korunma uygulamalarının döviz kuru oynaklığının ticaret üzerindeki olumsuz etkisinin zayıflattığını tezini akla getirmektedir. Türkiye örneğinde döviz kurundaki oynaklığın inracat üzerindeki etkisi anlamsız bile olsa oynaklığın getirdiği riskin ve riskin ticaret azaltıcı etkisinin göz ardı edilmemesi gerektiği değerlendirilmektedir. Çünkü Türkiye ekonomisinde giderek daha da önem kazanan cari açığın sürdürülebilirliği sorununun, kur oynaklığındaki şiddetli bir artış ile birlikte, literatürde beklenen endişeleri haklı çıkaracağı düşünülmektedir. Özellikle ithalata dayalı ihracat yapısı, artış eğilimindeki cari açık ve bu açığın tedavi edici yöntemler yerine sıcak para ile finanse edilmesi bu endişeleri daha da artırmaktadır. Diğer yandan son dönemde cari açığın finansmanı için uygulanan yüksek faiz politikası, yerli firmaları ülke içinden değil de ülke dışından döviz cinsinden borçlanmaya sevk etmektedir. Özel sektör dış borcundaki yükselme cari açığın sürdürülebilirliğini olumsuz etkilemekte ve finansal kırılganlığı artırmaktadır ki bu kırılganlık kur oynaklığında büyük bir dalga yaratabilecek güce eriştiğinde ticaret üzerinde olumsuz bir etki yaratabilecektir.

Sonraki çalışmalara öneri olarak bir yandan cari açığın sürdürülebilirliği, ülke içi faiz oranlarının yüksekliğivefirmalarınartandövizcinsiborçluluğunun firmaların ihracat performansları üzerine etkisi diğer yandan literatürün ısrarla vurguladığı, hedging uygulamalarının döviz kuru oynaklığının ihracat üzerindeki olumsuz etkisini azaltacağı tezinin Türkiye örneğinde sınanması gerektiği düşünülmektedir. Ayrıca Türkiye örneğinde meta analizi yapmak için döviz kuru oynaklığı ile ihracat ilişkisini inceleyen yeterince çalışma yapılmış gibi gözükmektedir. Ulaşılan amprik sonuçlar seçilen sektör, dönem, ülke, yönteme göre değişiklik gösterdiği için yapılacak meta analizi çalışmasıyla Türkiye örneğinde ulaşılan çelişki sonuçlarını nedenleri ortaya konabilir diye değerlendirilmektedir.

\section{KAYNAKLAR}

Acaravcı, A., \& Öztürk, İ. (2002) "Döviz Kurundaki Değişkenliğin Türkiye İhracatı Üzerine Etkisi: Ampirik Bir Çalışma" Review of Social, Economic and Business Studies, 2, 197-206.

Akhtar, M. A., \& Hilton, R. S. (1984) "Exchange Rate Uncertainty and International Trade: Some Conceptual Issues and New Estimates From Germany And The US"Federal Reserve Bank of New York, Research Paper, (8403).

Alessandria, G., Kaboski, J., \& Midrigan, V. (2008) Inventories, Lumpy Trade, and Large Devaluations (No. w13790), National Bureau of Economic Research.

Alessandria, G., Pratap, S., \& Yue, V. Z. (2014) "Export Dynamics in Large Devaluations" Working Paper 12269, http://crei.cat/conferences/ICF14/papers/ yue.pdf (05.05.2015).

Altintaş, H., Cetin, R., \& Öz, B. (2011) "The Impact of Exchange Rate Volatility on Turkish Exports: 19932009" South East European Journal of Economics and Business, 6(2), 71-81.

Arize, A. C., Osang, T., \& Slottje, D. J. (2000) “Exchangerate volatility and Foreign Trade: Evidence from Thirteen LDC's" Journal of Business \& Economic Statistics, 18(1), 10-17.
Arize, A. C., Osang, T., \& Slottje, D. J. (2008) “Exchangerate Volatility in Latin America and Its Impact on Foreign Trade" International Review of Economics \& Finance, 17(1), 33-44.

Asseery, A., \& Peel, D. A. (1991) "The Effects of Exchange Rate Volatility on Exports: Some New Estimates" Economics Letters, 37(2), 173-177.

Bahmani-Oskooee, M., \& Hegerty, S. W. (2007) "Exchange Rate Volatility and Trade Flows: A Review Article" Journal of Economic Studies, 34(3), 211-255.

Bahmani-Oskooee, M., \& Hegerty, S. W. (2009) "The Effects of Exchange-rate Volatility on Commodity Trade Between the United States and Mexico" Southern Economic Journal, 1019-1044.

Bailey, M. J., Tavlas, G. S., \& Ulan, M. (1986) “Exchangerate Variability and Trade Performance: Evidence for theBig Seven Industrial Countries"Weltwirtschaftliches Archiv, 122(3), 466-477.

Balcılar, M., Bal, H., Algan, N., \& Demiral, M. (2014) "Türkiye'nin İhracat Performansı: İhracat Hacminin Temel Belirleyicilerinin İncelenmesi (1995-2012)" Ege Akademik Bakış, 14(3), 451.

Bergin, P. R., \& Lin, C. Y. (2012) "The Dynamic Effects of a Currency Union on Trade" Journal of International Economics, 87(2), 191-204. 
Bernard, A. B., Jensen, J. B., Redding, S. J., \& Schott, P. K. (2009) The Margins of US Trade (Long Version) (No. w14662), National Bureau of Economic Research.

Broll, U. (1997) “Exchange Rate Risk, Export and Hedging" International Journal of Finance \& Economics, 2(2), 145-150.

Broll, U., \& Eckwert, B. (1999) “Exchange Rate Volatility and International Trade" Southern Economic Journal, 178-185.

Chaney, T. (2005) "Liquidity Constrained Exporters" http://www.researchgate.net/ profile/ Thomas_Chaney/publication/228343788_ Liquidity_constrained_exporters / links/0deec51c06bf9ad6b5000000.pdf (05.05.2015).

Chit, M. M. (2008) "Exchange Rate Volatility and Exports: Evidence from the ASEAN-China Free Trade Area"Journal of Chinese Economic and Business Studies, 6(3), 261-277.

Chit, M. M., \& Judge, A. (2011) "Non-linear Effect of Exchange Rate Volatility on Exports: The Role of Financial Sector Development in Emerging East Asian Economies"International Review of Applied Economics, 25(1), 107-119.

Chit, M. M., Rizov, M., \& Willenbockel, D. (2010) "Exchange Rate Volatility and Exports: New Empirical Evidence from the Emerging East Asian Economies" The World Economy, 33(2), 239-263.

Chou, W. L. (2000) "Exchange Rate Variability and China's Exports" Journal of Comparative Economics, 28(1), 61-79.

Chowdhury, A. R. (1993) "Does Exchange Rate Volatility Depress Trade Flows? Evidence from Errorcorrection Models"The Review of Economics and Statistics, 700-706.

Çiftçi, N. (2014) "Reel Döviz Kuru Oynaklığının Türkiye'nin Avrupa Birliğine İhracatı Üzerine Etkisi: Ar (1) - Garch $(1,1)$ ve ARDL Tekniği ile Analiz" Sakarya iktisat Dergisi 3:72-112.

Clark, P. B. (1973) “Uncertainty, Exchange Risk, and the Level of International Trade" Economic Inquiry, 11(3), 302-313.

Coes, D. V. (1981) "The Crawling Peg and Exchange Rate Uncertainty" Exchange rate rules: The theory, performance and prospects of the crawling peg, 113136.

Ćorić, B., \& Pugh, G. (2010) "The Effects of Exchange Rate Variability on International Trade: A MetaRegression Analysis" Applied Economics, 42(20), 26312644.
Cushman, D. O. (1983) "The Effects of Real Exchange Rate Risk on International Trade.Journal of international Economics" 15(1), 45-63.

Cushman, D. O. (1986) "Has Exchange Risk Depressed International Trade? The Impact of Third-country Exchange Risk" Journal of International money and Finance, 5(3), 361-379.

De Grauwe, P. (1988) "Exchange Rate Variability and the Slowdown in Growth of International Trade" Staff Papers-International Monetary Fund, 63-84.

Dekle, R., \& Ryoo, H. H. (2007) “Exchange Rate Fluctuations, Financing Constraints, Hedging, and Exports: Evidence from Firm Level Data" Journal of International Financial Markets, Institutions and Money, 17(5), 437-451.

Dellas, H., \& Zilberfarb, B. Z. (1993)“Real Exchange Rate Volatility and International Trade: A Reexamination of the Theory" Southern Economic Journal, 641-647.

Doğanlar, M. (2002) "Estimating the Impact of Exchange Rate Volatility on Exports: Evidence from Asian Countries" Applied Economics Letters, 9(13), 859863.

Ethier, W. (1973) "International Trade and the Forward Exchange Market"The American Economic Review, 494-503.

Franke, G. (1991) "Exchange Rate Volatility and International Trading Strategy" Journal of International Money and Finance, 10(2), 292-307.

Giovannini, A. (1988) "Exchange Rates and Traded Goods Prices" JournalofInternational Economics, 24(1), 45-68.

Gotur, P. (1985) "Effects of Exchange Rate Volatility on Trade: Some Further Evidence" Staff PapersInternational Monetary Fund, 475-512.

Hooper, P., \& Kohlhagen, S. W. (1978) "The Effect of Exchange Rate Uncertainty on the Prices and Volume of International Trade"Journal of International Economics, 8(4), 483-511.

Hsu, K. C., \& Chiang, H. C. (2011)“The Threshold Effects of Exchange Rate Volatility on Exports: Evidence from US Bilateral Exports" The Journal of International Trade \& Economic Development, 20(1), 113-128.

Huchet-Bourdon, M., \& Korinek, J. (2011) "To What Extent do Exchange rates and their Volatility Affect Trade?" OECD Trade Policy Working Paper Series, (119).

Kamal, Y., Haq, H., Ghani, U., \& Khan, M. M. (2012) "Modeling the Exchange Rate Volatility, Using Generalized Autoregressive Conditionally Heteroscedastic (GARCH) Type Models: Evidence 
from Pakistan"African Journal of Business Management, 6(8), 2830-2838.

Kasman, A. (2003) "Türkiye'de Reel Döviz Kuru Oynaklığı ve Bunun İhracat Üzerine Etkisi: Sektörel Bir Analiz" Uludağ Üniversitesi İktisadi ve Idari Bilimler Fakültesi Dergisi, 22(2), 169-186.

Kawai, M., \& Zilcha, I. (1986) “International Trade with Forward-futures Markets under Exchange Rate and Price Uncertainty" Journal of International Economics, 20(1), 83-98.

Kenen, P. B., \& Rodrik, D. (1986) "Measuring and Analyzing the Effects of Short-term Volatility in Real Exchange Rates" The Review of Economics and Statistics, 311-315.

Kızıldere, C., Kabadayı, B., \& Emsen, Ö. S. (2013) “Dış Ticaretin Döviz Kuru Değişmelerine Duyarlılığı: Seçilmiş Gelişmekte Olan Ülkeler Üzerine Bir İnceleme" Atatürk Üniversitesi İtisadi ve Idari Bilimler Dergisi, 27(3):41-54.

Koray, F., \& Lastrapes, W. D. (1989) “Real Exchange Rate Volatility and US Bilateral Trade: a VAR Approach" The Review of Economics and Statistics, 708-712.

Köse, N., Ay A. \& Topallı N. (2008) “Döviz Kuru Oynaklığının İhracata Etkisi: Türkiye Örneği (19952008)" Gazi Üniversitesi Iktisadi ve Idari Bilimler Fakültesi Dergisi, 10(2):25-45.

McKenzie, M.D. (1999) "The Impact of Exchange Rate Volatility on International Trade Flows" Journal of Economic Surveys, 13(1):71-106.

Naknoi, K. (2015) “Exchange Rate Volatility and Fluctuations in the Extensive Margin of Trade" Journal of Economic Dynamics and Control, 52:322-39.

Özbay, P. (1999) The Effect of Exchange rate Uncertainty on Exports: A Case Study for Turkey, Central Bank of the Republic of Turkey.

Pesaran, M. H., Shin, Y., \& Smith, R. J. (2001) "Bounds Testing Approaches to the Analysis of Level
Relationships" Journal of applied econometrics, 16(3), 289-326.

Poon, S. H., \& Granger, C. W. (2003) "Forecasting Volatility in Financial Markets: A Review" Journal of economic literature, 41(2), 478-539.

Rey, S. (2006) "Effective Exchange Rate Volatility And Mena Countries Exports To The Eu." Journal of Economic Development, 31(2):23-54.

Saatçioğlu, C., \& Karaca, O. (2011) “Döviz Kuru Belirsizliğinin İhracata Etkisi: Türkiye Örneği" Doğuş Üniversitesi Dergisi, 5(2), 183-195.

Sauer, C., \& Bohara, A. K. (2001) “Exchange Rate Volatility and Exports: Regional Differences between Developing and Industrialized Countries" Review of International Economics, 9(1), 133-152.

Sengupta, J. K., \& Sfejr, R. E. (1997) "Modelling Exchange Rate Volatility" International Journal of Systems Science, 28(6), 617-624.

Sercu, P., \& Vanhulle, C. (1992) “Exchange Rate Volatility, International Trade, and the Value of Exporting Firms" Journal of Banking \& Finance, 16(1), 155-182.

Sevim, C., Oztekin, A., Bali, O., Gumus, S., \& Guresen, E. (2014) "Developing an Early Warning System to Predict Currency Crises" European Journal of Operational Research, 237(3), 1095-1104.

Tang, H. C. (2014) “Exchange Rate Volatility and IntraAsia Trade: Evidence by Type of Goods"The World Economy, 37(2), 335-352.

Thursby, J. G., \& Thursby, M. C. (1987) "Bilateral Trade Flows, the Linder Hypothesis, and Exchange Risk" The Review of Economics and Statistics, 488-495.

Vergil, H. (2002) "Exchange Rate Volatility in Turkey and its Effect on Trade Flows" Journal of Economic and Social Research, 4(1), 83-99. 